\title{
Reflexões sobre a ideia de justiça e humanismo: uma abordagem no campo da fenomenologia de Emmanuel Lévinas
}

\author{
Moacyr Motta da Silva ${ }^{1}$
}

Resumo: O presente estudo procura apresentar uma reflexão sobre as concepções de justiça e de humanismo para desenvolvê-las como disciplinas nos cursos de graduação em Direito. O autor seleciona como fundamento teórico para o trabalho o pensamento de Emmanuel Lévinas. Entre os objetivos da escolha temática destacam-se: a necessidade de o operador do Direito (advogado, promotor de Justiça, juiz, professor de Direito) notadamente pesquisar, refletir acerca das instituições da justiça e do humanismo. O estudo propõe uma revisão no currículo dos cursos de graduação em Direito com a introdução de disciplinas: Antropologia, Sociologia (Filosofia: ética, estética moral e artes).

Palavras-chave: Justiça. Humanismo. Educação.

\begin{abstract}
The present study shows some reflections about Justice and Humanism conception to be developed as an education process on the Law under-graduation courses. The author selects as theoretical fundament to the work, the phenomenological thinking by Emmanuel Lévinas. Among the thematic choice of the objects, it is highlighted the need of the law operator (lawyer, state attorney, judge, mastership, chief of police, and other positions of the same duty) to researching, reflecting and applying the Justice institution, with Humanism fundaments. The study proposes a curriculum review on the Law under-graduation courses of subjects about Humanism, Anthropology, Sociology (Philosophy: ethics, aesthetics, moral and arts.).
\end{abstract}

Keywords: Justice. Humanism. Education.

\section{Introdução}

Neste início do terceiro milênio, a Educação ofertada como uma das políticas públicas no Brasil, encontrada nos cursos de bacharelado em Direito, ainda mantém estruturas curriculares centradas nas tradicionais

1 Doutor e mestre em Direito pela Universidade Federal de Santa Catarina. Professor aposentado da Universidade Federal de Santa Catarina no curso de Direito e nos programas de mestrado e doutorado. Professor titular do Programa de Pós-Graduação Stricto Sensu em Ciência Jurídica da Universidade do Vale do Itajaí, cursos de doutorado e mestrado. Membro da Academia Catarinense de Filosofia. E-mail: moacyrmotta@yahoo.com.br. 
disciplinas do direito substantivo e do direito formal. As técnicas de procedimentos, o processo digital, a reforma do Código Civil, do Código de Processo Civil e Penal constituem parte do discurso do direito tradicional. As teses em torno da celeridade do processo, do tempo razoável do processo surgem como bandeira inovadora da rapidez da prestação jurisdicional. Cria-se o imaginário de que a satisfação da sociedade, em relação à Justiça do Estado é medida, tão somente, por estatísticas quantitativas do tempo da prestação jurisdicional. Em oposição contrária a essa visão, vêm despontando nas academias, na sociedade civil, nas diversas representações de classe, novas ideias, debates, reflexões voltadas para a necessidade da humanização da Justiça. O estudo com esta preocupação constitui o objetivo principal do artigo. Procura-se, neste trabalho apresentar ideias e fundamentos que permitam contribuir para uma nova leitura do ensino sobre humanismo, no planejamento dos cursos de Direito para o modelo brasileiro.

\section{Teoria do Conhecimento - visão panorâmica}

O conhecimento como teoria pesquisa-se, estuda-se, desenvolvese, classifica-se por diferentes ângulos de visão. ${ }^{2}$ Nenhum deles pode

2 A Teoria do Conhecimento, também denominada Epistemologia, desenvolvese, progride, estaciona, avança segundo o tempo e o espaço. As condições políticas, econômicas, sociais e históricas constituem fatores decisivos na transformação do conhecimento. Nesta linha de raciocínio, a Teoria do Conhecimento pode ser aceita como uma medida do saber, do conhecimento. Ela se ocupa, igualmente, da origem do conhecimento. Tem-se que ela representa certa generalidade de saberes universais constituídos por elos de ideias, de observações, de experiências, de reflexões. A Teoria do Conhecimento não representa algo retilíneo, uniforme, monolítico, senão um acúmulo de saberes que no devir do tempo tem sua dinâmica própria. O conhecimento não apresenta tese, proposição de caráter definitivo. Há sempre um contrário demonstrado por ângulo distinto do anterior. É a incessante busca do novo que se acumula ao anterior que contribui para o crescimento desta. Em cada fase da História, em cada espaço territorial aparecem pensadores que não se satisfazem com o mundo que se lhes apresenta. Seja nas artes, seja nas ciências da natureza, nas ciências humanas, nas ciências físicas, na religião, na metafísica, na moral, na ética. Por este ponto de vista, pode-se dizer que o conhecimento apresenta-se setorial, em campos distintos. Cada âmbito do saber, do conhecimento é medido por seus resultados para o bem da Sociedade. Em cada área do conhecimento reina um modelo próprio de linguagem e de 
explicar o início ou o fim de uma parcela ou a totalidade do mundo, em grau absoluto. Por igual entendimento, parecer haver o consenso, segundo o qual não existe uma teoria universal do conhecimento igual e absoluta para todos, em todos os tempos e lugares. Aceitando-se essas premissas, convenciona-se que a noção de Teoria do Conhecimento, para o presente estudo, inspira-se em certas ideias absorvidas no pensamento de Platão. A obra do filósofo é vasta e o tema encontra-se em vários livros. Assim, opta-se por tocar a noção de conhecimento em Platão, numa breve fração de textos. Segundo depreende-se das lições do destacado filósofo, o conhecimento tem início com a experiência sensível. No diálogo entre Sócrates e Teeteto, o primeiro indaga ao segundo: "Volta pois, para o começo, Teeteto, e procura explicar o que é conhecimento.” (PLATÃO, 2001). ${ }^{3}$ Motivado a responder a indagação de Sócrates, Teeteto inicia o diálogo ao afirmar que a sensação constitui um dos elementos do conhecimento. O interlocutor assinala, por exemplo, a noção de frio ou de calor, já que as duas sensações adversas revelam um estado sensível do corpo humano. Prossegue o diálogo, com o entendimento de que a sensação do frio existe, em certas circunstâncias, para uns, mas não para outros. Nesta variação de valor não há sensação universal. O assunto adentra à ideia de aparência, o peso de certa coisa, o repouso, o movimento, o fluxo das coisas. Tudo se mostra variável no tempo e no espaço. O Ser que parece deixar de existir não representa finitude, nem o sinônimo de deterioração, senão a transformação do Ser em outro Ser. Esta concepção parece ser contínua, pois todos os elementos do mundo encontram-se em constante transformação. ${ }^{4}$ As lições que se obtêm do diálogo entre Sócrates e Teeteto contribuem para o estudo da Teoria do Conhecimento. Entre elas, podem-se assinalar: a sensação, o peso, o volume, o odor, a

significações. A Teoria do Conhecimento, em princípio, parte de duas origens distintas para explicar o conhecimento: a) empirismo básico, o que considera impossível a aquisição do conhecimento de certa realidade afastado do uso não empírico da razão. b) racionalismo básico. Defende a tese, segundo a qual certos conhecimentos são adquiridos pelo emprego da razão pura. A tendência do pensamento contemporâneo reconhece o conhecimento numa síntese da experiência e da razão.

3 Diálogos. Parágrafos 226 p. par.151e (Trad. direta do Grego por Carlos Alberto Nunes).

4 op. cit. parágrafos 151 e a 153 b. 
visão, o movimento, o repouso, enfim as coisas que tocam os sentidos do Homem, inclusive as ideias, as ilações, as deduções representam elementos indicativos do conhecimento. O estudo da teoria de Platão revela, igualmente, que o conhecimento nasce das ideias. Ou seja, por duas fontes, uma delas deriva da experiência, do dado empírico, a seguinte originase da razão pura, independente da experiência. Na linha de argumentos desenvolvida no referido diálogo, Platão fala do ser e o não-ser. O ser para o filósofo assume a ideia de potência, ou o conhecimento. O não-ser denota a ignorância, algo sem potência. A categoria potência representa, no pensamento de Platão, a motivação do ser, a parte dinâmica que se ocupa em explicar, descobrir algo do ser e os limites do não-ser (PLATÃO, 1996). ${ }^{5}$ Os argumentos da Teoria do Conhecimento absorvidos na teoria de Platão servirão de fundamentos sobre o estudo da justiça no presente trabalho. Mais precisamente, encontrar argumentos para demonstrar que a justiça pressupõe conhecimento pela razão e a experiência histórica. Justiça denota potência, conhecimento, experiência e razão de um mesmo ser.

\section{Teoria do Conhecimento - Ceticismo}

Particular linha do pensamento que se ocupa da Teoria do Conhecimento recai no denominado ceticismo. O ceticismo põe em dúvida a verdade absoluta.

Uma das principais teorias acerca do ceticismo entende que o espírito humano não possui capacidade para alcançar, com certeza, nenhuma verdade como generalidade. Visto o ceticismo deste ângulo, não há certeza, nem verdades absolutas. Qualquer proposição enunciada com sentido de certeza sofre a oposição dessa teoria.

O estudo da Epistemologia dedica-se, igualmente, ao conhecimento chamado de "senso comum". Constitui certo grau de cultura sem correspondência com o conhecimento das ciências em geral e da metafísica. O "senso comum" constitui um fenômeno que interessa às Ciências Sociais, diante da massa de pessoas que a ele adere. As chamadas crenças, palpites constituem formas de pensamento e de agir desprovidas de verdade

5 A República, par. 477 a 479a. 
ou de falsidade. Essas formas de pensar e de agir fundam-se em práticas particulares desprovidas de qualquer dado científico. A sua aceitação e difusão entram no imaginário social. Registre-se, porém, que certas práticas e efeitos constituem preocupação para a Ética, o Direito e a Metafísica.

\section{Teoria do Conhecimento - Epistemologia Relativista}

Recentes correntes do pensamento contemporâneo colocam-se numa linha intermediária, chamada Epistemologia Relativista. Entre duas concepções que se contrapõem, mediante dois extremos do pensamento, os epistemólogos optam pela relativização do entendimento. Talvez essa postura os coloque no sentido de humildade científica.

Considerando a Teoria do Conhecimento em áreas do saber, parece razoável pensar que a Epistemologia Relativista comporta ser observada nas Ciências Humanas. Aceitando-se o entendimento de que o Ser humano comporta ser classificado em distintas visões, ou seja, como ente racional, ético, moral, psíquico, espiritual e histórico, parece correto dizer que um dos traços que distinguem um grupo humano em relação a outro está nos critérios estabelecidos para cada um deles. A ideia de certeza, de verdade que se extrai das diversas classificações, por exemplo, do Homo-sapiens, Homo-moralis, Homo-phaber, Homo racionalis, Homo emotivus e outros grupos reforça o entendimento, segundo o qual a teoria da Epistemologia Relativista ganha maior aceitação no âmbito das Ciências Humanas, ou seja, não há necessidade da elaboração de proposições com grau de certeza ou de verdade absolutas.

\subsection{Sócrates}

Os diálogos criados por Platão sobre o pensamento de Sócrates ${ }^{6}$ são encontrados em inúmeros textos. Por opção, o autor dedica a pesquisa

6 Sócrates. A cronologia de Sócrates é imprecisa. Sabe-se que nasceu antes de Platão. Natural de Atenas. Filho de Sofrônio, de profissão escultor e da mãe chamada Fenáreta que se ocupava da profissão de parteira. Tomando-se como parâmetro a estratificação social da Grécia antiga, Sócrates era considerado pobre. Mesmo assim, dedicou-se à meditação e aos estudos de filosofia. Diante da vocação para estudos filosóficos, nunca 
sobre a ideia de Justiça no texto Platão - Diálogos III Apologia de Sócrates Críton e Fédon. ${ }^{7}$ Os dois principais interlocutores de Sócrates são nominados no título do livro. O diálogo desenvolvido por Platão tem por ponto central a condenação e a defesa de Sócrates. Do ponto de vista Político, a acusação, a prisão e a condenação de Sócrates assumiram notoriedade e registro histórico por conta de Platão, seu ex-discípulo. Na juventude, Platão conheceu Sócrates, a quem o reconhecia como o grande sábio. Consta que Platão desde a juventude tinha desapreço por políticos de Atenas. Na visão de Platão, a chamada democracia ateniense não passava de pequeno grupo de malfeitores políticos envolvidos com manobras políticas. Segundo narrativas de Críton e Fédon, os argumentos alegados pelos inimigos de Sócrates para a sua prisão não passavam de uma trama política para eliminá-lo. Entre elas, citam-se: a) ter sido acusado da morte de Leon de Salamina (um general que não quis obedecer às ordens do grupo dos trinta tiranos de Atenas, supostamente envolvidos com a ideia de mudança de Regime Político da cidade); b) corromper a juventude ateniense com manifestações contrárias à religião da época. Sócrates não aceita a inverdade que lhe fora atribuída. Prefere a morte traiçoeira à verdade forjada. A condenação imposta consistiu em ministrar-lhe uma taça do poderoso veneno cicuta. Nos textos de Platão, Críton e Fédon participaram dos últimos momentos de vida de Sócrates. O primeiro, Críton, dedicava-se às ideias sobre o "dever", no sentido de indicar que o homem na sociedade política orienta-se pelo "dever" no sentido do bem comum. O segundo, Fédon, acreditava na existência da alma considerada imortal. A própria concepção de justiça provém das ideias de Platão, colocadas nas bocas de Criton e Fédon. A leitura do texto revela duas concepções de justiça. A primeira aparece como

se interessou pela política nem por atividades econômicas. Viveu sempre afastado da vida pública, embora fosse um ardoroso crítico dos políticos. Era considerado chefe da aristocracia intelectual. Foi mestre de Platão (GUTHRIE, 1991, p. 416).

7 "Não sou homem que fale para ganhar dinheiro e que me calem, peço que se moderem. Estou tanto ao dispor dos pobres como dos ricos para que interroguem ou, se preferirem, para que eu lhes ponha a eles e me ouçam o que tenho a dizer-lhes. Se um ou outro dentre ele se tornar honesto ou desonesto, não é justo tornarem-me responsável, pois que nunca prometi nem dei qualquer lição a alguém.” (Platão: Diálogos III Apologia de Sócrates Criton e Fedon Par. XXI). 
virtude. A segunda, de natureza pública. Em várias passagens do texto, Sócrates invoca seu modo de agir na Sociedade ateniense. Sua autodefesa sustenta-se nas palavras, nos argumentos que o condenado afirmava serem verdadeiros. Jurava que durante sua vida sempre pautou suas ações segundo os costumes morais de Atenas.

Ao entardecer do dia de sua execução, Sócrates sentou-se, novamente, e conversou com um dos guardas. O funcionário incumbido de lhe dar o veneno lhe revelou certa piedade, comparando-o a outros presos a quem ministraria a taça do mortal líquido. Isso porque os demais condenados à morte mostravam-se coléricos, em contraste com a atitude de Sócrates, de postura calma e generosa. Mas tudo teria que ser cumprido, por ordem do magistrado. "Resta-me, como funcionário, pessoalmente anunciar-te a Deus.” Após chorar, retirou-se, dizendo-lhe: "procura suportar da melhor forma o que é necessário”. Sócrates observa que, em sua permanência, ali, esse homem, de ofício executor da morte, revelava generosidade e solidariedade. Trata-se de excelente homem. Sócrates pede a Críton que lhe traga o veneno, pois já está preparado. Críton sinaliza a um de seus servidores para administrar a taça de veneno a Sócrates. Respondelhe o executor que bastava tomar o líquido e iniciar uma caminhada até que sentisse um peso sobre as pernas. Em seguida, deitar-se para que o veneno, a cicuta se espalhasse por todo o corpo. Sócrates bebe por inteiro o poderoso veneno. Sem mostrar alteração no rosto ou dores, logo em seguida Sócrates apresentava um olhar fixo. Críton fecha-lhe a boca e os olhos. Palavras finais de Platão: "O homem de que podemos bendizer, que entre todos os de seu tempo que nos foi dado conhecer, era o melhor, o mais sábio e o mais justo.” A vida e obra de Sócrates têm sua memória escrita para a posteridade nos textos de Platão.

\subsection{Platão}

Entre os livros escritos pelo filósofo que tratam da justiça, provavelmente, A República ocupa um espaço de destaque (PLATÃO, 1996). O nome república deriva do latim. Escreve-se Res-pública. ${ }^{8}$ Platão

8 Um dos consagrados tratadistas de Platão considera um erro de tradução denominá-la - O Estado sobre a Justiça (GUTHRIE, 1991, p. 416). 
teoriza a ideia de justiça a partir de um regime político, ou seja, só há justiça considerada em uma sociedade politicamente organizada. O objeto da justiça é o Ser humano. Platão distingue o homem justo do injusto. Aquele que vive em comunidade, em coexistência com seus semelhantes necessita ser perfeitamente bom. Para tanto, há necessidade de conhecer a natureza humana. Uma visão distorcida de um Ser em relação ao outro pode motivar um juízo de injustiça. Para isto, o justo precisa ter conhecimento da natureza de cada um com quem se relaciona. Platão teoriza que é no meio social, na cidade, que tem origem a justiça. Por esta observação, Platão considera a justiça como instituição política. Conhecer as necessidades de si e dos outros contribui para a compreensão da Justiça. Platão, acerca das necessidades da Comunidade, classifica pela ordem de importância: a) os alimentos; b) a habitação; c) os vestuários. ${ }^{9}$ Platão, ao discutir sobre a natureza do homem, parece colocar-se como verdadeiro teórico da Antropologia e da Sociologia. Platão reconhece que o humano mostra-se igual ao outro, porém com naturezas diferentes. Uns possuem habilidades de execução, enquanto outros não a possuem. Tais diferenças existem nas atividades da lavoura, nos ofícios, como o sapateiro, o costureiro, na medicina. Outros homens dispõem de grande força física que a empregam em trabalhos pesados. As habilidades artísticas de todos os gêneros representam, igualmente, uma parcela de homens que se dedicam à expressão do belo, do harmonioso. Platão descreve uma cidade imaginária, pela qual a justiça representa a mais elevada das virtudes. A maior forma do Ser humano adquirir as virtudes morais e intelectuais está na educação. A formação moral da criança tem início nos primeiros anos de vida. Neste particular, chama a atenção do autor para a seguinte advertência de Platão: "Logo devemos começar a vigiar os autores de fábulas, e selecionar as que forem boas, e proscrever as más”. ${ }^{10}$ Embora apareça implícita, na teorização da justiça no pensamento de Platão, ela só existe dentro de organização política (Estado). As duas categorias usadas por Platão: "boas e más” formuladas na educação da Virtude, requerem cuidado, prudência nas suas exegeses. Neste particular, talvez o emprego do princípio do meio termo (o que se apresenta equidistante de cada um

\footnotetext{
9 Par. 369 d.

10 Par. 377 c.
} 
dos extremos) constitua uma das formas para medir os excessos de valores de cada uma delas. Este critério tem por fundamento a justiça no viés da política.

\subsection{Aristóteles e a ideia de justiça ${ }^{11}$}

O elemento moral que impulsiona o ser espiritual a praticar ato de justiça está no respeito ao seu semelhante. A justiça pressupõe, sempre, o outro (Alter). Significa que o Ser humano não pode pensar a ideia de justiça para si próprio. Significa que a ideia de justiça comporta a integração do ser como expressão do gênero humano. A excelência moral constitui manifestação da mente, que conduz à preferência pelo que considera correto. Preferência designa a vontade deliberada por algo aceito para um fim verdadeiro. Em sentido amplo, a preferência pode levar às coisas boas, como pode conduzir às coisas más.

\subsection{Justiça como fundamento da lei ou política}

Essa modalidade de justiça funda-se na lei. Também denominada Justiça Política. Ela se classifica de duas formas: Justiça Distributiva e Justiça Corretiva ou Comutativa. Como regra, a justiça distributiva pressupõe relação de hierarquia unindo ação do governante em relação ao governado. Trata-se de subordinação político-jurídica. Efetua-se mediante ato de decisão da autoridade. Atua na esfera entre público e privado. Entre os polos da relação da justiça distributiva, o sujeito ativo incide no governante. O polo passivo recai no governado ou nos governados. O objeto da justiça distributiva se constitui de pagamento em dinheiro, de honrarias, da distribuição de cargos, da fixação de critérios sobre tributos, da distribuição de deveres. Na justiça distributiva, por se tratar de forma de igualdade de razões, o julgador adquire poderes para realizar critério de avaliação de ordem social, de educação, econômica notadamente. Nesta modalidade, aparece claro o sentido formal de justiça, posto que é a lei que lhe dá forma. $\mathrm{O}$ ato de injustiça nesta categoria

11 Aristóteles (384aC $-322 \mathrm{aC}$ ) nascido em Estágira, atualmente (Stravó) território da Macedônia, no ano de 384 a.C. Aristóteles morreu em Cálcis, na Eubéia, em 322 a.C. Filho de Nicômacos, médico e amigo de Amintas II, rei da Macedônia. 
envolve o desigual. Considera-se injusto o que não observa o princípio da igualdade. Aristóteles estabelece que a igualdade não é de natureza numérica, senão igualdade de razão. A justiça distributiva considerada como um dos critérios buscar o justo, e toma por medida o mérito da pessoa individualmente considerada. Nela, a proporcionalidade não se funda em propriedade sobre quantidades numéricas, mas na generalidade. Trata-se de uma proporção de igualdade de razões. O justo, nesta concepção, corresponde ao meio termo entre duas igualdades de razão. $\mathrm{O}$ proporcional corresponde ao meio termo entre dois extremos. Representa uma igualdade, chamada igualdade de razões. As pessoas consideradas iguais recebem quantidades iguais de coisas a serem repartidas. O julgamento fundado por qualquer dos dois princípios será injusto se não considerar as qualificações pessoais e cada uma das pessoas. Na aplicação do Princípio da Justiça da Igualdade, distingue-se a pessoa em relação à coisa. Igualam-se pessoas entre si e não pessoas e coisas.

\subsection{Justiça corretiva ou comutativa}

Este outro critério de justiça nasce, igualmente, da vontade da lei. Denomina-se também justiça comutativa. O termo comutativo designa o contrato que estabelece obrigações recíprocas, dentro do qual as pessoas se obrigam a cumpri-lo. As partes envolvidas são equivalentes. Envolve troca ou permuta. Vincula duas pessoas entre si, por ato de vontade ou não. O âmbito de aplicação da justiça corretiva dá-se sob duas modalidades: relações voluntárias e involuntárias. Integram as relações voluntárias, a venda, a compra, o empréstimo a juros, o contrato de penhor, o empréstimo sem juros, o contrato de depósito e o de locação. Consideram-se relações involuntárias, fraudulentas e ilícitas, o furto, o adultério, o envenenamento, o lenocínio, o desvio de escravos, assassinato por traição, o falso testemunho, o assalto, a prisão, o homicídio, o roubo, a mutilação, a injúria e o ultraje. As partes envolvidas nas relações da justiça corretiva submetem-se ao princípio da igualdade no mais elevado sentido, ou igualdade absoluta. Inexiste ideia de relatividade. Em princípio, todos são iguais nas relações perante a justiça corretiva. Não importa se determinada pessoa é considerada boa ou má na Sociedade. 
A palavra justo, no idioma grego, é escrita (díkaion). ${ }^{12}$ Já o termo $(\text { dikha })^{13}$ designa o que se divide ao meio. Logo, a palavra (dikhastés), ${ }^{14}$ do mesmo idioma grego, significa juiz, a pessoa que, por autoridade da Sociedade política, julga um caso em concreto, divide ao meio.

O seguinte critério de justiça denomina-se Equidade.

No idioma grego, a palavra equidade (epieíkeia) (GUTHRIE, 1999, p. 388 $)^{15}$ designa correção da lei. ${ }^{16} \mathrm{O}$ termo equidade, empregado por Aristóteles, denota justiça como corretivo da lei. ${ }^{17}$

Vale destacar que na aplicação da justiça com equidade não se considera injusta a lei genérica, por não prever hipóteses de particularidades normativas. A equidade corresponde à justiça nos limites do caso concreto. A equidade não constitui forma complementar de justiça, senão a própria justiça. O justo legal significa o justo por equidade. Por ela, observa-se a interpretação moderada e prudente da lei diante do caso particular. A justiça por equidade designa a justiça no sentido particular, não alcançado pela generalidade da lei. A justiça por equidade exige do Juiz amplo conhecimento, não só da lei que regula a realidade que lhe é submetida, mas sobretudo dos princípios gerais do direito que compõem o sistema normativo. A equidade impõe-se como regra do princípio geral de justiça.

\subsection{Tomaz de Aquino}

O estudo focaliza aspectos do pensamento de Tomaz de Aquino voltado à concepção de justiça. ${ }^{18} \mathrm{~A}$ importância das ideias do filósofo

12 ARISTÓtELES. Ética a Nicômacos. Trad. Mário da Gama Kury. 3. ed. Brasília: Editora Universidade de Brasília. c 1985, 1992 par. 1132 a.

13 Op. cit. par.1132a.

14 Op. cit. par. 1132a.

15 Ver página 457 da mesma obra.

16 Op. cit. p. 388.

17113710 .

18 Tomaz de Aquino nasceu na comunidade na Roccasseca, Itália, no ano de 1225. Descendia de família nobre, estirpe de Aquino. Foi educado em Monte Cassino, transferindo-se depois para Nápoles, onde estudou artes liberais. Entrou para a Ordem 
em relação à Filosofia do Direito encontra-se na forma pela qual o pensador modificou a linha do pensamento escolástico da Filosofia Cristã. O Tratado de Justiça elaborado por Tomaz de Aquino encontra-se na Súmula Teológica - Summa Theologiae. ${ }^{19}$ Tomaz de Aquino foi leitor e pesquisador da filosofia de Aristóteles. Em suas reflexões consegue adequar à doutrina cristã, as concepções de seu mestre, sobre a virtude, a justiça, a lei. A contribuição de Tomaz de Aquino consiste em assimilar o pensamento de Aristóteles, de índole filosófica, para teorizá-la no pensamento cristão (RUSSEL, 2001, p. 216). A escolástica inspiravase nas ideias do pensamento do neoplatonismo. ${ }^{20}$ Provavelmente, por esse motivo, os escritos de Tomaz de Aquino continuam a ser objeto de indagações para o mundo contemporâneo. Para compreender a ideia de justiça, o teólogo discute, primeiramente, a noção de direito. Considera direito a prescrição contida na norma. O teólogo classifica o direito em três fontes: direito natural, ${ }^{21}$ direito positivo ${ }^{22}$ e o direito divino. ${ }^{23}$

Dominicana, renunciando a todas as riquezas do mundo, com exceção das ciências. Estudou, mais tarde, teologia e filosofia, sob orientação de Alberto Magno, seu coirmão e mestre nas universidades de Paris e Colônia. No ano de 1252, Tomaz de Aquino voltou a Paris onde colou grau acadêmico e ensinou durante alguns anos. Faleceu no ano de 1274, no Mosteiro de Fossa Nova, entre Nápoles e Roma, a caminho de Leão.

19 Suma Teológica constitui tratado da ciência teológica. Elaborada no período da universidade medieval, cristaliza síntese do pensamento cristão sobre aspectos políticos, éticos e teológicos relativos ao Estado, à família, ao homem. O estudo acha-se estruturado em 16 volumes. No presente trabalho, a pesquisa centraliza-se no seguinte tomo: AQUINO, S. T. Suma de Teologia. III Parte II-II (a). Trad. Ovídio Calle Campo et al. Madrid: Biblioteca de Autores Cristianos. 1995. 612p.

${ }^{20}$ Neoplatonismo. Denota a fusão da filosofia de Platão com doutrinas religiosas, pitagóricas e outras. A escola de Atenas orientou o Neoplatonismo no sentido teológico, porém anticristão. Em outros lugares, combinou-se o pensamento cristão e neoplatônico. No Islamismo, no Judaísmo e no Cristianismo, há combinações de ideias que se podem considerar de neoplatonismo. O neoplatonismo teve influência na filosofia medieval e renascentista. No cristianismo, a ideia de imortalidade da alma, desenvolvida por Platão, constitui o neoplatonismo. In: BLACKBURN, Simon. Dicionário Oxford de Filosofia. Trad. Desidério Murcho et al. Rio de Janeiro: Jorge Zahar. 1997, 437p.

${ }^{21}$ C. 57 a I

22 C. 57 a I

${ }^{23}$ Deve-se destacar que Tomaz de Aquino, como filósofo do pensamento cristão da Idade Média, teve o cuidado de separar o âmbito do direito divino do direito natural. Na 
Este não se confunde com o direito positivo, nem com direito natural. A vontade humana constitui a fonte criadora do direito positivo. O direito natural apresenta-se imutável e idêntico para todas as pessoas. O direito natural é ditado pela razão natural do homem. ${ }^{24}$ Resulta da essência racional do homem. Mostra-se imutável e universal. O direito natural revela-se igual em toda parte. Representa a inclinação do homem para agir em conformidade com o bem e evitar o mal. O direito natural em determinado tempo histórico distingue-se do direito divino. ${ }^{25}$ Decorre das coisas naturais da vida em Sociedade. A ideia de justo para o direito natural corresponde à ação em conformidade com o respeito ao outro. Embora o direito natural não tenha a mesma matriz do direito positivo, as regras entre um e outro não colidem. $\mathrm{O}$ ato humano que afronta a lei natural não pode ser recepcionado como justo no plano do direito positivo. Segundo o pensador, o Direito Divino regula-se pela lei divina. ${ }^{26}$ Ela assume prescrições universais exigíveis a todo ser humano. Provém da concepção de um ente divino, transcendental atemporal. $\mathrm{O}$ amor ao próximo, benevolência, humildade, solidariedade constituem algumas regras de ordem, de inspiração divina. O amor a Deus, o respeito à consciência divina representam prescrições, segundo São Tomaz de Aquino como concepção do Direito Divino.

As coisas humanas regem-se pelo direito positivo. ${ }^{27}$ Há, portanto, distinção entre lei divina e lei como regra dos homens. A lei do direito positivo representa sua expressão na Constituição Política da Sociedade humana organizada.

passagem do capítulo 57 a.1, consta “que lo sagrado es ley divina; en cambio, el derecho es ley humana." A seguir, lê-se no Capítulo 57 a.2 "El derecho divino no es derecho natural, ya que soprepasa la naturaleza humana.” Aqui, certamente, encontra-se uma das matrizes teóricas que distinguem o direito natural do direito divino. ASSIM ESTÁ ESCRITO

24 C. 57 a 2.

25 C. 57 a 3.

26 C. 57 a 1.

27 C. 57 a.1. 
Tomaz de Aquino distingue o direito natural do direito positivo. ${ }^{28}$ Chama de direito positivo aquele criado pelo homem. ${ }^{29}$ Como categoria de ato humano, o direito positivo expressa-se mediante lei. Sua função política é regular a vida em Sociedade, por isso tem caráter geral. O direito positivo representa, essencialmente, um direito político, visto que decorre de atos da vontade humana. A leitura da obra de Tomaz de Aquino (AQUINO, 1995, III Parte II-II a), após explicitar as variáveis da justiça, revela que o tema aparece, igualmente, em dois níveis: justiça geral e justiça particular. ${ }^{30} \mathrm{~A}$ primeira corresponde à ação humana orientada pelas virtudes. A vontade individual, que decorre da livre consciência de si. Ela inclina-se pela realização de ações virtuosas, tais como a bondade, a humildade, o perdão, a solidariedade, a justiça. Chama-se injusto, do ponto de vista da justiça geral, aquele que transgride um comando relativo às ações virtuosas. O hábito, o agir humano representa um dos pontos essenciais da virtude. A justiça particular, na teoria de Tomaz de Aquino, apresenta-se em dois níveis: justiça comutativa e justiça distributiva. ${ }^{31}$

A justiça particular opera-se entre as pessoas, em caráter particular. Significa compreender certa pessoa no sentido individual, em relação à comunidade, como a parte do todo. Em outras palavras, o individual está para a comunidade, assim como a parte está para o todo. Logo, o que é comum ao todo é comum à parte. Esse fenômeno decorre da própria essência humana. O vínculo que une os homens entre si, do ângulo da justiça é de natureza ética. Para o filósofo, a virtude não existe parcialmente, mas no seu todo. O filosofo dá, como exemplo, o Sol que ilumina os corpos no planeta, em todas as latitudes, atingindo a todos, com o mesmo brilho e calor. ${ }^{32}$
28 C. 57 a 2.
29 C. 57 a 2.
30 C. 58 a 7.
31 C. 61 a 2.
32 C. 58 a 4. 


\subsection{Hobbes}

O estudo do pensamento de Hobbes revela a possibilidade de o pesquisador abordar, entre outras áreas de saber, tanto temas ligados à Teoria Política quanto à Filosofia da Moral. Do ponto de vista da primeira disciplina, Hobbes teoriza a concepção da criação de um pacto, pelo qual os homens despojam-se voluntariamente de seus direitos originários e os atribuem a um Soberano. Essa entidade política ideal adquire a prerrogativa de impor a lei e considerar o que é justo e o injusto. Hobbes considera que, anteriormente à instituição do pacto político, os homens lutavam entre si movidos por interesses particulares. A cooperação, a compreensão, a sensibilidade pelo seu semelhante não existiam. $\mathrm{O}$ egoísmo, a ganância, o desrespeito ao seu semelhante mostravam que o homem, por natureza, mostra-se insociável. Esse quadro de relações humanas Hobbes o descreve como "estado de Natureza". A consciência da Sociedade humana passou a aceitar a ideia, segundo a qual, artificialmente se devesse criar um contrato social. Nesse contexto, da passagem do estado de Natureza para o Estado Artificial, o Ente disciplinaria o egoísmo, a ganância, a liberdade, os interesses particulares em troca da ordem e da paz. Surge, assim, a figura do Estado, em 1atim, "civitas". A obra pode ser classificada como teoria política. Hobbes vê como única forma de salvação do Estado, a existência de um poder que domine, com autoridade plena, todas as divergências políticas internas e conflitos de interesses particulares.

A segunda disciplina, assim denominada na Filosofia de Hobbes, corresponde à Filosofia da Moral; mediante a criação do Estado, exclusivo criador da lei.

A concepção primeira de justiça, teorizada por Hobbes, tem origem nas leis da natureza. Guiado pela razão, o ser humano escolhe, livremente, a forma de convivência. A razão orienta-o a firmar pacto de convivência e confiança mútuas, entre todos os homens. Diante do pacto, fica estipulado que cada um, em particular, cumpra o acordo celebrado e, em decorrência da celebração do pacto, a lei impõe a todos o seu cumprimento. O justo é aquele que observa a lei que emana da convenção. Aquele que rompe o estabelecido no pacto é considerado injusto. Neste sentido, a ideia de 
justiça, que chamamos de segundo momento, nasce do pacto ajustado. A partir da instituição do pacto político, considerado válido pela adesão de seus membros, funda-se a justiça, com força de princípio. Do ponto de vista da virtude moral, considera-se homem justo aquele que, por hábito age na busca da justiça. O homem justo, por hábito, é considerado virtuoso. Logo, a ideia de justiça corresponde à ideia de virtude. A injustiça, nesta concepção, constitui vício. HOBBES considera a justiça como o maior valor moral da Sociedade política. A justiça, como expressão de pacto ideal, proporciona segurança às instituições políticas. Aceitando o pensamento dos escolásticos, Hobbes considera que a "justiça é a vontade de dar a cada um o que é seu”. A ideia de justiça, que se consagra como princípio, resulta da razão. Antes da criação do pacto político, não se pode falar de injustiça, nem de justiça. Por este raciocínio, a ideia de justiça nasce da vontade dos homens, mediante o estabelecimento ideal de pacto político.

Um dos fundamentos da justiça consiste na observância das regras firmadas pelo pacto político. Justo é aquele que observa as regras do contrato político. Neste sentido, a razão indica a necessidade de manter-se permanentemente o compromisso com a justiça.

A lei moral, ou ciência da virtude orienta o ser humano a agir em conformidade com a justiça, a equidade e a misericórdia. A bondade humana constitui virtude moral voltada para a convivência pacífica em Sociedade. A misericórdia guarda o sentido de apelo moral para a ajuda ao próximo. A vontade, nesta linha de entendimento, representa um dos fundamentos de sua Filosofia da Moral. A amabilidade, a caridade, a esperança, a benevolência são formas de virtude moral teorizadas por Hobbes.

A Filosofia da Moral em Hobbes apresenta dupla tarefa. A primeira procura chegar a uma definição de justiça que seja capaz de responder às condições científicas. Em outras palavras, que os termos, os vocábulos empregados sejam aceitos como discurso coerente, evitando-se a ambiguidade. A segunda tarefa consiste em demonstrar que os conceitos são, racionalmente, necessários. A leitura da Filosofia da Moral de Hobbes leva a deduzir que o conceito de justiça não pode ser isolado dos valores morais construídos pela Sociedade humana. Hobbes demonstra que somente pela razão o homem distingue a boa da má ação, como virtude moral. 


\subsection{Kelsen}

O jovem filósofo do Direito, Hans Kelsen (1881-1973), inspirado nas teorias desenvolvidas no Círculo de Viena, bem como no Positivismo Lógico, elaborou uma notável obra, que chamou Teoria pura do Direito (KELSEN, 1991). Acredita-se que o pensamento positivista de Hans Kelsen se fortaleceu por frequentar as reuniões do Círculo de Viena. Kelsen concebe o Direito Positivo como fenômeno jurídico de visão geral, em oposição a uma ordem jurídica especial. O objetivo dessa teoria consiste em saber o que é o direito, (Recht). Assinala que a indagação sobre qual deve ser o direito pertence à Política do Direito. Portanto, a Teoria Pura do Direito não se preocupa em saber qual deva ser o melhor direito. Considerada nesta linha de pensamento, a Teoria Pura do Direito procura isolar de seu âmbito todas as questões metafísicas e ou valorativas (teoria dos valores). Kelsen assinala que o direito perdeu sua pureza, nos séculos XIX e XX, ao incluir no conceito do jurídico categorias de outras disciplinas, como a Sociologia, a Política, a Psicologia, a Ética, a Moral. Todo esse sincretismo de saberes contribuiu para tornar o conceito do direito, algo impuro. Kelsen formula a tese, segundo a qual o direito constitui um ato de vontade do legislador, do humano. Afasta a ideia do direito de ordem metafísica ou divina. Teoriza que a significação jurídica não permite ser entendida pelos sentidos, senão objetivamente na interpretação da norma em face do fato descrito. O direito deve ser entendido, mediante relação entre a norma de conduta objetivamente válida em relação ao objeto da realidade. Questões do tipo vontade, próprias de ordem subjetiva, ou intenção não fazem parte do conceito de direito. Este representa uma ordem de conduta humana, sem nenhuma intervenção metafísica.

O direito, na teoria de Kelsen, representa um sistema de normas, cuja unidade decorre de outra chamada fundante. Trata-se de norma hipotética, ideal, abstrata. A partir dela, todas as demais derivam do mesmo fundamento de validade. A particularidade desse sistema consiste em que o direito imuniza todas as disciplinas metafísicas, como a ética, a justiça, a moral. O direito é considerado a priori, sem qualquer relação com a experiência. O direito articula-se pelo dever-ser (Sollen, do idioma alemão), sem relação com o ser (Sein, do mesmo vernáculo). 
Na concepção da Teoria Pura do Direito, o Estado, enquanto Sociedade politicamente organizada constitui a sede exclusiva do direito. Toda norma jurídica representativa do direito organiza-se nos limites políticos do Estado. ${ }^{33}$

\subsection{Rawls}

A obra Uma teoria da justiça (RAWLS, 1997) consagra o professor norte-americano John Rawls, na condição de um dos filósofos de expressão do século XX. Viveu entre os anos de 1921 a 2002, nos Estados Unidos da América do Norte, lecionou na Universidade de Harward, e sua obra de renome acha-se voltada para a justiça como equidade. Como pensador, elabora uma teoria, puramente ideal, abstrata. Significa que toda a estrutura, objeto e objetivos desenvolvem-se e concluem em torno de proposições utópicas. Considera a justiça como a mais elevada virtude das instituições sociais. Neste viés, a justiça é pensada como função pública. A leitura da teoria de Rawls parece um convite feito ao leitor, no sentido de aceitar como razoáveis determinadas premissas que por si constituem a estrutura do trabalho. A Teoria de Rawls chama-se também Contratualista. $\mathrm{O}$ autor observa que cada ser humano possui algum sentido de justiça; aceitando-se, igualmente, que neste estágio do pensamento, o ser humano não vive isolado do outro, senão em coletividades existenciais. A consciência social cria a ideia de que nada se torna mais importante para todos. A partir dessa concepção, a Sociedade de homens livres elabora um pacto de natureza social. Rawls reconhece que essas ideias não são originais posto que se inspiram em inúmeros pensadores. ${ }^{34} \mathrm{O}$ êxito, o sucesso do pacto social decorre da convenção de uma justiça como equidade. Anteriormente ao pacto coletivo, imagina-se a existência de um Estado de Natureza, em cujo estágio cada um agia por si, um verdadeiro caos com predomínio da infelicidade, da injustiça. O fundamento essencial da teoria de Rawls decorre do princípio da igualdade. Ou seja, com a estipulação do pacto, todos os membros da Sociedade encontram-se em condições de igualdade. A seguinte proposição do autor corresponde

\footnotetext{
33 Por escolha do autor, deixa-se de focalizar a produção normativa de Direito Internacional.

34 Platão, Aristóteles, São Thomaz de Aquino, Jean Jacques Rousseau e outros.
} 
ao Princípio de Justiça por Equidade. A Sociedade instituiria a criação de uma Assembleia de homens com o propósito de transformar em regra geral, obrigatória a Justiça, chamada por Equidade. Essa instituição teria a incumbência de governar a Sociedade. Os dois princípios de justiça, corolários da equidade: direitos iguais no sistema de liberdades básicas; as desigualdades sociais e econômicas seriam compensadas mediante a oportunidade de todos (direito).

Sinteticamente, pode-se deduzir que a Teoria da Justiça por Equidade ou Contratualista de Rawls revela uma visão formal de justiça. Essa concepção abstrata de justiça omite, evita a discussão acerca da ética, da moral, do sentimento humano. Essas instâncias constituem parte da natureza do Homem, por isso, não podem ficar à margem de qualquer teoria de Justiça. Acrescente-se a estes argumentos, a ausência de contextualização entre a Teoria por Equidade elaborada por Ralwls e a realidade política, social norte-americana, marcada por diferentes graus de oportunidades e desigualdade em relação aos Direitos Humanos.

\subsection{Osvaldo Ferreira de Melo: Fundamentos da Política do Direito}

A leitura do livro de Osvaldo Ferreira de Melo intitulado Fundamentos da Política Jurídica (MELO, 1994) chama a atenção do leitor sobre a singular classificação elaborada pelo autor. Após pesquisar textos de pensadores da clássica cultura grega como Platão, o autor elabora um estudo das principais linhas do pensamento sobre o Jusnaturalismo, de M. P Peres, o Normativismo de Kelsen, o Empirismo de Alf Ross e o Culturalismo de Miguel Reale. A pesquisa não se exaure nas referidas correntes do pensamento. Para cimentar, para amalgamar suas ideias, o autor busca inspiração temática, entre outros, em David Hume, Jeremy Benthan, Locke, Rousseau, Kant, Rawls, Ottfrie Hoffe e Reale.

A partir dessa base teórica, o pensador propõe uma síntese denominada Fundamentos da Política Jurídica. As proposições, as reflexões contidas no trabalho, por sua riqueza temática, por suas ideias inovadoras rompem com a Clássica Dogmática do Direito e se consagra como uma moderna Teoria do Direito. Acerca da ideia de justiça formulada pelo ius-filosofo, o autor propõe que o político do 
Direito opere com quatro concepções de justiça: “a) como ideal político de liberdade e de igualdade; b) como relação entre as reivindicações da Sociedade e a respostas que lhe dê a norma; c) como a correspondência entre o conhecimento científico sobre o fato (conhecimento empírico da realidade) e a norma em questão; d) justiça como legitimidade ética”. Uma das importantes proposições formuladas pelo autor consiste no entendimento de que, se a norma de direito colidir com a norma moral, poderá essa norma ser considerada injusta. Neste particular, roga-se licença a Kelsen, para tomar, aqui, metáfora conhecida por "chave de ouro”, e aplicá-la no texto formulado pelo tratadista. Releva observar que o Prof. Osvaldo vê a justiça no contexto social. O autor parece projetar a justiça num sentido da Sociedade, pensamento que desloca a justiça como categoria travada nas relações particulares, para envolvê-la como fenômeno Social (harmonia do ser com o mundo).

\section{A concepção de justiça e o pensamento fenomenológico de Emmanuel Lévinas ${ }^{35}$}

A fenomenologia tomada para o presente estudo compreende parte da filosofia que se ocupa da compreensão da natureza humana, de suas vocações, escolhas, tendências, mitos, valores no sentido do ser em si e ser do mundo. Um universo de intersubjetividades inter-relacionais que gravita nas relações humanas chama a atenção do observador por assumir sentido de universalidade. Na fenomenologia, essa forma de sentir, de aspirar, de buscar um valor universal chama-se justiça. A partir desse recorte temático, investigam-se aspectos do pensamento de Emmanuel Lévinas com o objetivo de encontrar fundamentos para este trabalho. A concepção de justiça que se inspira no pensamento de Lévinas aparece na inter-relação entre o Sujeito e o Outro. Ela representa ao mesmo tempo um imaginário, um sentimento, um ideal que brota do mundo que se

\footnotetext{
${ }^{35}$ Emmanuel Lévinas Nasceu na Lituânia em cujo tempo de juventude completou os estudos secundários. O filósofo era de origem judia. A seguir, foi atraído para dedicar-se à Filosofia em Paris. Pesquisou temas ligados à Fenomenologia com Edmund Husserl. Foi um dos admiradores de Martin Heidegger. Seus últimos anos de vida foram voltados ao estudo da Fenomenologia; Emmanuel Lévinas faleceu em Paris, no ano de 1995.
} 
considera. A justiça aparece como manifestações subjetivas criadas pela consciência universal e captadas da experiência historicamente vivida. Nas inter-relações humanas, a ideia de justiça defronta-se com estados humanos fundados no amor diante do ódio, na alegria em relação à tristeza, a alegria no individual em relação ao coletivo, no sagrado diante do profano. Essa complexa rede de intersubjetividades produz-se na consciência social.

\subsection{Justiça: uma visão antropológica - aspectos}

A Teoria do Conhecimento permite explicar o aparecimento do homem, entre outras, por duas fontes do pensamento. A primeira acha-se escrita nos textos bíblicos. No Livro do Gênesis, 1-2, o homem é revelado na condição de criatura concebida por Deus. No citado livro lê-se: "Deus disse: 'Façamos o ser humano à nossa imagem e segundo a nossa semelhança, para que domine sobre os peixes do mar, as aves do céu, os animais domésticos, todos os animais selvagens e todos os animais que se movem pela terra'. Deus criou o ser humano à sua imagem, à imagem de Deus o criou. Homem e mulher, ele os criou”. ${ }^{36}$ No mesmo, o Livro do Gênesis consta que Deus formou o Ser humano a partir do "pó apanhado no solo". Em seguida, soprou-lhe as narinas, com o "sopro da vida." Uma das exegeses dessa metáfora cristã leva à ideia, segundo a qual o Ser Humano é constituído de matéria e espírito. Deus criou o homem do pó, da terra, mas a vida teve início diante do sopro vindo do espírito divino. Significa pensar que o Ser humano na linguagem do Gênesis não representa só matéria e nem apenas espírito, senão a combinação dos dois elementos.

A segunda fonte que tenta demonstrar o surgimento do homem corresponde à ciência antropológica (LINTON, 2000). Esta área do saber teoriza que o homem teria se originado de uma ordem natural como os demais seres que habitam a Terra; derivaria de uma ordem especial de mamíferos chamados primatas. Teria surgido após o aparecimento de outros seres vivos. Importante assinalar que essas observações fundam-

${ }^{36}$ BÍBLIA SAGRADA. Trad. Conferência Nacional dos Bispos do Brasil. Brasília: CNBB, 2008. 1563 p. 
se em dados que, progressivamente, vêm sendo aceitos pela maioria da comunidade científica. Trata-se de conhecimento antropológico que ainda se encontra em fase de indagações. As teses sobre esta temática ainda se encontram no mundo das hipóteses. Daí o sentido de probabilidade das proposições, muitas delas aceitas pela comunidade científica. A ciência explica que o Ser humano na classificação dos mamíferos superiores encontra-se numa escala especial, posto que se distingue, pelo grau de aprendizado.

Uma das linhas de pesquisa da antropologia classifica o aparecimento do Ser humano pelo gênero de (Neanderthal, mais tarde como Homo Sapiens). Após, nomina-o Homem Moderno. As diversas classificações revelam um crescente processo de evolução do Homem. O fenômeno de transformação do Homem não é observado apenas em sua estrutura óssea, muscular, tecidos da pele, a cor, o tamanho do crânio, a forma ereta do corpo, bem como os seios da face e demais traços. Além dessas particularidades, outras igualmente se destacam. São as que correspondem, por exemplo, à razão, aos sentimentos, à inteligência, à vontade. Considerado o homem por essa complexidade, leva-se a pensar que ele possui por natureza inata as referidas propriedades. Entre os sentimentos humanos destacados, um deles surge nas inter-relações da vida em grupo: o ideal da necessidade da organização social; a aspiração por uma vida em grupo voltada para o equilíbrio e a justa distribuição dos valores. Esses ideais fundados na consciência social chamam-se justiça. O calendário humano, enquanto instrumento de registro do tempo, não possui a data do aparecimento da justiça no seio da Sociedade. Ela desperta espontaneamente, na Sociedade organizada. Nesta linha de pensamento, parece certo afirmar que a justiça constitui ideal que nasce das relações intersubjetivas do Homem diante da organização da Sociedade. Ela é própria da vida coletiva do Homem. O espaço, o tempo, a cultura modelam a ideia de justiça, segundo os valores criados pela consciência social. Releva assinalar que na filosofia grega da Antiguidade, Aristóteles (1992) considera o homem um animal ${ }^{37}$ social (Segundo Aristóteles, é da sua natureza a busca da vida em Sociedade. Ou seja,

${ }^{37}$ Ética a Nicômacos. Trad. de Mário da Gama Kury, c1985, par. 1097 b. 
conviver, estabelecer relações sociais com outros seres de sua espécie. Essa concepção considera-o igualmente um Ser político, no sentido da criação de estratégias para coexistir com seus semelhantes em Sociedade organizada.

Lévinas (1980, p. 145) ${ }^{38}$ assinala que o homem não está no planeta vindo de um espaço intersideral. O filósofo fala em morada ou elemento, que o homem idealiza um espaço, um local dentro do qual procura viver, exercer certo grau de liberdade. A casa representa para o filósofo o utensílio material da morada. A casa compreende o espaço físico criado pelo homem para nela recolher-se, para afastar-se dos importunos, como, igualmente, da investida de outros animais perigosos. Na ordem dos interesses morais, Lévinas coloca a morada entre os principais meios para exercer a liberdade. Porém, ela só não constitui um fim para a felicidade do homem. Lévinas observa que a ideia da morada representa uma intenção de todos os membros do grupo social. ${ }^{39} \mathrm{~A}$ doçura da vida não se encontra apenas no recolhimento da morada. Ela aparece no momento em que o Ser humano entra em contato com seu semelhante. Tem início a coexistência humana. Na inter-relação humana se estabelece um universo de permuta de elementos materiais e, sobretudo, de valores éticos, estéticos, morais, religiosos. Na mesma inter-relação humana, instalam-se conflitos, choques de interesses de diversas naturezas. Lévinas chama de mundo nu a relação sujeito-objeto tal como se apresenta a realidade. ${ }^{40} \mathrm{O}$ pensador assinala que a ciência e a arte servem para revestir os elementos (da realidade) de significação de beleza de linguagem. A filosofia de Lévinas parece conduzir a ideia de inter-relação no sentido da morada, na qual cada membro opte pela solidariedade, a cooperação em lugar do isolamento, a compreensão em lugar da cega resistência, o perdão em lugar da vingança, o amor em lugar do ódio, a aceitação das diferenças em lugar da unicidade. A estética da ética surge na ação humana exemplificada nas polaridades acima descritas. Entende-se que a ideia de ocupação da morada em sentido de isolamento, sem aproximação com o seu semelhante, deixando-se de abrir para o mundo torna o homem embrutecido. Ao contrário, a solidariedade,

38 Totalidade e infinito. 3. ed. Trad. José Pinto Ribeiro.

39 Op. cit. p. 146.

40 Op. cit. p. 64. 
o interesse pelo interesse do Outro, a hospitalidade, a atenção, constituem sentimentos que o Ser humano necessita exercitar continuamente. A vida da morada se torna leve mediante a consciência social de cooperação, de solidariedade. A morada vista por Lévinas parece oferecer denúncia no sentido moral do mundo contemporâneo. A apologia da mentira, a exaltação da inverdade, a veneração aos bens materiais, o endeusamento da imagem, a divinização da riqueza de bens materiais, a profanação do sagrado na família, o desvio de finalidades das instituições públicas e outros desvios leva a Sociedade a aceitar, lentamente a existência de grupos de imorais (desvio de conduta moral). Parece que as palavras de Lévinas sugerem uma reconstrução da morada no sentido da Ética. Na concepção do autor do presente artigo, a justiça representa o modelo de instituição ideal, não só jurídica, histórica e política, mas sobretudo vocacionada à estética da ética. Esta mudança depende da reconstrução de novo modo de pensar e agir do homem em Sociedade.

\subsection{A Justiça como manifestação da razão}

A concepção de justiça revela-se como instituição criada pela razão humana (SILVA, 2010). A justiça constitui produto da Sociedade politicamente organizada. A consciência social representa a matriz da justiça, como expressão cultural. A justiça revela, sempre, uma utopia, uma meta moral a ser alcançada. A justiça, no devir histórico, não possui ideia de limite. Ela não é exclusiva de departamento (setorial) da Organização da Sociedade. A justiça exige de cada um em particular ações moralmente justas. Ela torna-se exigível em todo tecido de relações individuais e coletivas (ação humana). Um dos princípios que norteiam a justiça consiste na proibição de que o ofendido procure, com suas próprias mãos, a reparação do dano (a lei disciplina as exceções civis e penais). A justiça não se considera hierarquicamente em grau superior ou subalterno de escalas políticas da Sociedade. Distingue-se, porém, no contexto da Organização Política, pela criação de órgão específico para declarar o direito (consultivo ou decisório - por exemplo, o Poder Judiciário no Brasil). A justiça, como instituição político-jurídica dispõe do poderdever de sanção. A sanção compreende a execução levada a termo, no cumprimento da vontade de lei. Esse princípio de direito representa a 
exigência da lei, por ato do juiz. A justiça legitima-se perante a consciência social na medida em que faz cumprir a vontade da lei, socialmente justa. A justiça representa criatura moral da Sociedade política organizada. Nesta linha de entendimento, a justiça não se inspira em teorias do tipo: cósmica, divina. É mutável no tempo e no espaço. A justiça assim pensada tem por objetivo a paz entre os homens. O seguinte princípio de justiça escolhido para o presente trabalho consiste na busca da educação do homem (políticas públicas). Essa, em princípio, representa a principal vocação da Sociedade Política Organizada. A educação como emanação da justiça orienta o homem para a convivência pacífica em Sociedade, o respeito aos princípios de direito, das leis, das instituições (públicas e particulares), e, principalmente, da dignidade da pessoa humana.

\subsection{Justiça e humanismo}

Inspirado no pensamento de Lévinas (1993), o tema a ser tratado neste tópico seleciona aspectos da ideia de Humanismo. ${ }^{41}$ Segundo palavras de Lévinas, o humanismo de nossa época encontra-se em crise. Aponta o autor que uma das fragilidades do humanismo tem sua fonte na ineficácia humana colocada em acusação, diante da abundância de agir pela extensão de nossas ambições (LÉVINAS, 1993). Assinala o filósofo que a Sociedade assiste à ruína do mito do homem. A persistir a falência do mito humano, surgirá uma ordem “nem humana, nem umana” (sic)

41 A palavra humanismo permite ser empregada em inúmeras áreas do saber. Nas teorias do Direito, nas teorias políticas, na Antropologia, na Sociologia, na História em geral, na Moral e outras disciplinas sobre a natureza do homem. O humanismo teorizado para este estudo compreende o Ser-humano dotado de um conjunto de elementos únicos: (Ser biológico, racional, ético, espiritual, moral, sensitivo). Esse complexo de entidades revela-se próprio, exclusivo na natureza humana. O humanismo ocupa-se do Serhumano como único Ser do reino animal titular de valores supremos de sua natureza humana. Humanismo tem sua fundamentação no valor do homem. O humanismo procura demonstrar que o Ser-humano representa o fim e não o meio de quaisquer projetos do planeta. Ele encontra-se hierarquicamente acima de todas as escalas de valores criadas pela Sociedade. As teorias que se dedicam ao humanismo voltam-se para a esperança, o ideal de bem-estar, da paz, da dignidade do homem em Sociedade. O humanismo procura despertar o pensamento segundo o qual o Ser humano constitui um Ser, igualmente, espiritual, ético, psíquico, moral. 
de futuras gerações orientadas por sistema dialético ou lógico-formal. ${ }^{42}$ Ou seja, a prevalência da forma em lugar da razoabilidade.

As palavras do filósofo parecem denunciar um universo de ações praticadas pelo homem movidas pela ambição, ou seja, a busca da satisfação de bens materiais em detrimento da elevação de valores éticos, morais, religiosos, próprios da natureza humana. Aceitando-se esse entendimento, pode-se adequá-lo, contextualizá-lo para certa realidade brasileira: a coexistência humana observada nas cidades e nos interiores vem sendo abalada pela ocorrência de ações humanas, consideradas deshumanas (crimes contra a vida, contra a honra, contra o patrimônio), desafiam a razão do homem. O quadro descrito permite inúmeras abordagens. Parece que, entre as possíveis formas de tratamento para o mal que assola a Sociedade, um deles revela-se comum para as diferentes sugestões: a educação. Particularmente, para o objeto deste trabalho, aponta-se a educação do humanismo. O viés da educação humanista projeta-se para o âmbito da justiça.

Motivando-se pelas ideias de Lévinas, pontua-se que entre as prováveis causas determinantes da debilidade do humanismo na esfera da justiça encontra-se a educação, mais precisamente nos cursos de graduação em Direito. ${ }^{43}$

A vivência adquirida no magistério das disciplinas que integram os currículos dos cursos de Direito no Brasil estimula-nos a assinalar que eles apresentam certa debilidade, superficialidade nos conteúdos voltados às áreas de Antropologia, Ética, Moral, Estética, Sociologia. Como gênero, as grades curriculares dos cursos de Direito no Brasil oferecem, além das áreas de base do Direito, (material e processual), tópicos sobre Filosofia do Direito; Bioética, Teoria do Direito; Antropologia Jurídica, Sociologia

\footnotetext{
${ }^{42}$ Nós assistimos à ruína do mito do homem, fim em si mesmo, deixando aparecer uma ordem nem humana, nem umana, ordenando-se certamente através do homem e das civilizações que ele teria produzido; mas subordinando-se, no fim das contas, pela força propriamente racional do sistema dialético ou lógico formal” (LÉVINAS 1993, p. 75).

${ }^{43}$ BRASIL. Lei no 9.394, de 24 de dezembro de 1996 - Estabelece as diretrizes e bases da educação nacional. A lei principal que regula e orienta os cursos superiores no Brasil, entre os quais o de Direito que a "Educação Superior tem por finalidade: 1- estimular a criação cultural e o desenvolvimento do espírito científico e do pensamento reflexivo".
} 
do Direito e Direitos Humanos. As grades curriculares não são fixas, podendo variar segundo a visão política da Instituição Jurídica do Ensino Superior. O principal foco dos currículos dos cursos de graduação em Direito, como já mencionado, acha-se voltado para o direito substantivo e o direito adjetivo ou formal. O ensino de graduação em Direito pouco ou quase nada se dedica às matérias acima referidas. O ensino do Direito orienta-se em geral pela leitura de livros sobre manuais do Direito e textos formulários destinados aos procedimentos judiciais. Parece haver um estímulo, premiação à memorização, em lugar da reflexão, da ilação. A bibliografia ofertada (Manuais, Formulários e Técnicas de Procedimento) parece desconhecer os autores clássicos do pensamento científico, da filosofia e das artes. No campo da estética, da ética, da moral, da religião, da metafísica, da política, a pedagogia do Direito, ressalvadas exceções, limita-se à formulação de conceitos operacionais. Há vozes nas academias que consideram disciplinas de Humanismo como conhecimento supérfluo, sem necessidade prática para o Direito.

A orientação pedagógica nos cursos de bacharelato em Direito raramente se dedica a partir de uma teoria a pesquisar e a refletir sobre os julgados pelas Cortes de Justiça do Brasil ou estrangeiras (por exemplo, extradição por motivos políticos; crimes envolvendo torturas; exclusão política e racial; a guarda de crianças por pais separados com domicílios e residências em diferentes países).

Em lugar de pesquisas dessa grandeza sobre Humanismo, o ensino do Direito dá ênfase aos polos de autor e réu. O estudo do Direito estimula a ideia de disputa de quem sabe melhor operar os códigos. O Direito é internalizado como instrumento de duelo, de conflito. A Instituição da Conciliação escassamente é ensinada como uma das formas de solução pacífica de Justiça.

A necessidade de revisão de uma Educação de Humanismo voltada para os cursos de Direito não se encerra com a outorga do título de Bacharel em Direito. O fenômeno reaparece com maior grandeza nos concursos para o ingresso nas carreiras da advocacia pública e ou privada, nas carreiras do Ministério Público, na magistratura e outras relativas ao poder de polícia. Os conteúdos exigidos nos programas de concursos repetem o mesmo nível, anteriormente ensinado. Com rara frequência, 
registram-se teses em concursos públicos que focalizam temas sobre humanismo. Diante deste quadro, pergunta-se qual a formação nesta área que possui o Bacharel em Direito.

Uma das respostas parece lúcida. A persistir o atual modelo pedagógico da Educação do Direito será o da involução. A reforma da Educação no Brasil destinada aos cursos de Direito surge com urgência.

A ideia de Justiça encontrada nos órgãos do Judiciário no Brasil parece limitar-se a relatórios estatísticos. A justiça é medida ou pelo número de processos julgados, ou pelas conciliações acordadas, sem se considerar o grau de satisfação do jurisdicionado. O mérito da causa parece colocado em segundo plano. Esse quadro produz, na consciência social, imagem da Justiça tal como o corpo sem alma, morta. Por isso, o presente estudo aparece com o objetivo de contribuir para um projeto pedagógico de Educação para os cursos de Direito. Visa a uma profunda mudança de paradigmas curriculares, envolvendo o Humanismo. Reconhece-se que projeto dessa envergadura e complexidade exige, entre outros fatores, tempo e vontade política.

\section{Conclusões}

Espera-se que o estudo ora realizado possa contribuir para o aperfeiçoamento da Educação de Humanismo nos cursos de graduação em Direito. A fundamentação da Educação de Humanismo na área do Direito visa a demonstrar que não se alcança o objetivo da justiça política exclusivamente na transmissão de conhecimentos de disciplinas fins (Direito Substantivo e Processual).

A história política revela que os grandes acontecimentos provocados pela mão do homem, como as guerras, os massacres, as devastações criminosas de vidas inocentes guardam íntima relação com questões econômicas, com desmedida noção de valores humanos. Igualmente, cenas de injustiça praticadas pelo homem, em suas inter-relações intersubjetivas têm a marca da falta de piedade, de solidariedade, de amor ao próximo. A Educação pelo Humanismo necessita ser desenvolvida no sentido de despertar no homem sua missão na Sociedade: a busca da convivência 
pacífica. Igual linha de entendimento volta-se para a Educação pelo Humanismo nos cursos de Direito. A fundamentação desenvolvida procurou demonstrar que o Operador do Direito, antes de tudo, é um Ser Humano. Do mesmo modo, reconhecer que em todos os litígios, controvérsias, desacordos, acham-se por trás vidas humanas. O estudo tem por objetivo despertar a consciência, o entendimento de que todo Ser Humano, acima de qualquer escala de valores constitui um Humano, contrário ao inumano (sic), segundo adverte Emannuel Lévinas. ${ }^{44}$

Embora a racionalidade constitua uma necessidade ao Operador do Direito, tal entendimento não pode ser levado fora de sua finalidade (instrumental-formal) $\mathrm{O}$ autor já demonstrou em trabalhos desta temática que o Direito nasce e convive com a sensibilidade. Há determinadas relações de intersubjetividades, notadamente de ordem moral, ética, social e política verificadas entre humanos que a racionalidade operativa, instrumental, por sua essência não consegue levar a termo (por exemplo, questões de família, de menores, de psicopatas, de intimidade moral, de convicção religiosa). Na área das relações entre Operadores do Direito vêm crescendo com significação, queixas, representações aos conselhos de ética, às corregedorias judiciais, acerca do tratamento desrespeitoso entre os profissionais dessas áreas. A ausência de Educação de Humanismo surge igualmente nas relações intersubjetivas travadas com os Operadores do Direito em relação ao cidadão comum (arrogância, maus tratos morais e até físicos, displicência, excessiva demonstração de poder político).

Justiça com humanismo aparece no meio jurídico quando é deixada de fora, pela falta de Educação de Conhecimento do operador jurídico. Diante destes argumentos, o autor formula as seguintes proposições: A Educação do Homem necessita ser orientada em dois sentidos: a) a prática do humanismo nas relações humanas ensinadas desde a infância; b) a reformulação de políticas públicas sobre a educação, mediante a transmissão pedagógica de conhecimentos sobre o humanismo. Esta palavra deve constituir o centro de irradiação de todos os valores e atenções da Sociedade organizada politicamente. A educação, nesta perspectiva, representa um processo pedagógico sem fim, portanto de permanente esforço de toda a Sociedade.

${ }^{44}$ Op. cit., p.75. 
Ao concluir, deve ser lembrado o pensamento de Emmanuel Lévinas: “o homem não é somente objeto mas também sujeito”. ${ }^{45}$ Parece que nesta frase o filósofo quer falar da inclusão do homem no processo de evolução da Sociedade. Sujeito ativo da Sociedade. O pensamento do filósofo contextualizado para o cenário da Justiça de nossos dias, inspira-nos a entender que o homem como Ser de si e do mundo não pode imaginar-se fora, isolado do complexo das inter-relações humanas. O texto parece demonstrar que o homem precisa ser o condutor de seu próprio destino. Entre os pontos de destaque no pensamento de Lévinas, imagina-se aquele que orienta o Homem como membro ativo na condução política da Sociedade. Ao Direito, ao lado de outras ciências, incumbe buscar, fomentar e promover a ação do homem, para a criação de regras justas, outras de ordem ética, estética, moral dotadas de humanismo.

\section{Referências}

AQUINO, S. T. Suma de Teologia. III Parte II-II (a). Trad. Ovídio Calle Campo et al. Madrid: Biblioteca de Autores Cristianos, 1995. 612p.

ARISTÓTELES. Ética a Nicômacos. Trad. de Mário da Gama Kury. 3. ed. Universidade de Brasília, 1992.

BÍBLIA SAGRADA. Trad. Conferência Nacional dos Bispos do Brasil. Brasília: CNBB, 2008. 1563p.

BLACKBURN, S. Dicionário Oxford de Filosofia. Trad. Desidério Murcho et al. Rio de Janeiro: Jorge Zahar, 1997. 437p.

BRASIL. Ministério da Educação e Cultura. Lei nº 9.394, de 24 de dezembro de 1996 - Estabelece as diretrizes e bases da educação nacional.

GUTHRIE, W. K. C. Historia de la filosofia griega.: introducción a Aristóteles. v. 6. Trad. Alberto Medina Gonzáles. Madrid: Editorial Gredos, 1999. 483 p.

45 LÉVINAS, Emmanuel (1906-1995) Humanismo do outro homem. Trat. Pergentino e outros. Petrópolis: Vozes, 1993. 
GUTHRIE, W. K. C. História de la filosofia griega. IV Platón: el hombre y sus diálogos, primera época. Trad. Álvaro Vallejo Campos et al. Madrid: Editorial Gredos, 1991.

KELSEN, H. Teoria pura do direito. 3. Edição. Tradução João Batista Machado. São Paulo: Martins Fontes, 1991. 371 p.

LÉVINAS, E. (1906-1995) Humanismo do outro homem. Trat.

Pergentino et al. Petrópolis: Vozes, 1993. 109 p.

LÉVINAS, E. Totalidade e infinito. Trad. José Pinto Ribeiro. 3. ed. Portugal, 1980. 310 p.

LINTON, R. O homem: uma introdução à Antropologia. Trad. Lavínia Vilela. São Paulo: Martins Fontes, 2000. 470 p.

MELO, O. F. Fundamentos da política jurídica. Porto Alegre: Sérgio Antônio Fabris Editor, 1994. 136p.

PLATÃO. A República. 8. ed. Trad. Maria Helena da Rocha Pereira. Lisboa: Fundação Calouste Gulbenkian, 1996. 513 p.

PLATÃO. Diálogos III Apologia de Sócrates - Criton e Fedon. 2. ed. Trad Fernando Meiro, Portugal. 166 p.

PLATÃO. Diálogos. Teeteto Crátilo. 3. ed. Trad. direto do Grego, Carlos Alberto Nunes. Belém: Editora Universitária. UFPA 2001. 226 p. ASSIM CONSTA DO LIVRO

RAWLS, J. Uma teoria da justiça. Trad. Almiro Pisetta e Lenita M. R. Esteves. São Paulo: Martins Fontes, 1997.

RUSSEL, B. História do pensamento ocidental. 4. ed. Trad. Laura Alves et al. Rio de Janeiro: Ediouro, 2001.

SILVA, M. M. Direito, justiça, virtude, moral e razão. 3. ed. Curitiba: Juruá, 2010. 265 p.

Recebido em: 15/01/2010 Revisado em: 28/02/2010 Aprovado em: 10/03/2010 